\title{
SHGs in BIHAR - A Examination of Their Saving Behavior and Saving Products
}

\author{
A. Sreenivas
}

\begin{abstract}
This study is related to exploring the scenario of saving by SHG members, it probes into the hurdles, the popular saving schemes among the SHG members, the reasons behind their popularity and the possible steps that can be taken to improve the saving scenario by $\mathrm{SHG}$ members.The study was carried out in Supaul District of Bihar State. The sample size for study was 300. The methodology used for the study was in - depth interview through Qualitative Research technique. The study deals withfactors (Education, Age, Term of association,Caste category, Loan granted or not, distance of bank, Meeting interval)affecting the saving behavior of SHG,the different saving product available to the SHG and the suitable saving products for the poor."
\end{abstract}

\section{INTRODUCTION}

A. overview:

This study is related to exploring the scenario of saving by SHG members, it probes into the hurdles, the popular saving schemes among the SHG members, the reasons behind their popularity and the possible steps that can be taken to improve the saving scenario by SHG members.

B. Justification for choosing Supaul district of Bihar: Bihar is one of the thirteen priority states which have been identified by NABARD for giving focused attention for increasing the microfinance outreach.Supaul District was selected for the study because it is one of the least developed districts of Bihar and in respect of most of the important parameterscompares unfavourably with the state averages as for example the district is predominantly rural with the share of rural population in the total population of the district being 94.9\%(Census India, 2011). The district falls in the lower bracket in respect of major district wise developmental indices of the state of Bihar.

\section{Research objective:}

1. To identify the factors affecting the saving behavior of SHG.

2. To identify the different saving product available to the SHG.

3. To find out the suitable saving products for the poor.

\section{RESEARCH OBJECTIVE AND APPROACH}

\section{A. Sources of information:}

Data were collected from the primary as well as secondary sources. Secondary data were collected from various sources, website of NABARD, RBI, Planning commission of India, Bihar Govt. etc., Annual report of RBI and NABARD were also studied. data regarding matured SHG were taken from Bank branches.The primary data were collected from Chhatapur block and Supaul block of Supaul District in the month of April and May 2011.

\section{Sampling:}

For the purpose of sampling first of all Supaul district was selected and 2 blocks of Supaul district were selected 1st in district headquarter 2 nd far from district headquarter. And 6 villages from each block were selected, 2 near Block headquarter, 2 from distant away from the Block headquarter and 2 near the border of the Blocks Altogether $12\{(2+2+2) x$ $2\}$ villages were included in sampling.6 villages of Supaul Block (Beena,Ghuran,Blwa,Ekma,Bariya and Parsama) and 6 villages of Chhatapur Block (Thoothee, Bhagwatpur, Udhampur, Madhopur, Pariyahee, Bhimpur) was taken as sample.A sample size of $300 \mathrm{SHG}$ members(25 from each village) is taken.

\section{THE FACTORS AFFECTING THE SAVING BEHAVIOR OF SHG}

\section{E. Variables :}

Education, Age, Term of association,Castecategory,Loan granted or not distance of bank, Meeting interval are taken as factors affecting saving behavior of SHG in Bihar

\section{F. Data Analysis}

To interpret the factors affecting regular saving, we used, the binary logistic regression model.

\begin{tabular}{|l|l|l|l|l|l|l|}
\hline Variables & $\mathrm{B}$ & S.E. & Wald & Df & Sig. & Exp(B) \\
\hline Education & 1.762 & .236 & 55.975 & 1 & .000 & 5.827 \\
\hline Age & -0.099 & 0.050 & 0.395 & 1 & 0.047 & 0.096 \\
\hline $\begin{array}{l}\text { Term of } \\
\text { association }\end{array}$ & 0.479 & .197 & 5.919 & 1 & .015 & 1.615 \\
\hline caste category & -1.312 & .199 & 43.656 & 1 & .000 & .269 \\
\hline $\begin{array}{l}\text { loan granted } \\
\text { or not }\end{array}$ & 1.679 & .201 & 45.789 & 1 & .001 & 3.458 \\
\hline $\begin{array}{l}\text { bistance of } \\
\text { meeting }\end{array}$ & -1.495 & .200 & 44.765 & 1 & .002 & 1.638 \\
interval & 0.566 & .210 & 7.258 & 1 & .007 & 1.762 \\
\hline Constant & -1.134 & .851 & 1.777 & 1 & .183 & .322 \\
\hline
\end{tabular}

B - This is the coefficient for the constant (also called the "intercept") in the null model. 
S.E. - This is the standard error around the coefficient for the constant.

Wald and Sig. - This is the Wald chi-square test that tests the null hypothesis that the constant equals 0 .

$\operatorname{Exp}(\mathbf{B})$ - This is the exponentiation of the B coefficient, which is an odds ratio. This value is given by default because odds ratios can be easier to interpret than the coefficient, which is in log-odds units.

Score and Sig. - This is a Score test that is used to predict whether or not an independent variable would be significant in the model.

df - This column lists the degrees of freedom for each variable. Each variable to be entered into the model,

Overall Statistics - This shows the result including all of the predictors into the model.

Education: -In the above table we can see that the significance level of Education in the above model is.000 and hence we can say that Education is a highly significant variable in saving. And the co-efficient is 1.672 i.e. for each unit of increase in education saving will increase by 1.672 unit

Age: - In the above table we can see that the significance level of age in the above model is. 047 and since this value is less than 0.05 hence we can say that age is significant variable in saving. And the co-efficient is -0.099 i.e. for each unit of increase in age saving will decrease by 0.099 unit. And from this result we can interpret that lower age SHG members have high savings as compared to higher age SHG members.

Term of Association: - Term of association is the duration with which a member is associated with SHG. In the above table we can see that the significance level of term of association in the above model is. 015 and since this value is less than 0.05 hence we can say that term of association is significant variable in saving. And the co-efficient is 0.479 i.e. for each unit of increase in term of association saving will increase by 0.479 unit. And from this result we can interpret that higher the term of association higher the savings.

Caste category: - caste category is the caste of SHG member. And here we have given lower no. to so called lower caste of society and vice-versa. In the above table we can see that the significance level of caste category in the above model is.000 and hence we can say that caste category is a highly significant variable in saving. And the co-efficient is -1.312 i.e. for each unit of increase in caste saving will decrease by 1.312 unit. And from this result we can interpret that so called upper castes have lower savings as compared to so called lower castes

Loan granted: - In the above table we can see that the significance level of loan granted in the above model is.001 and hence we can say that loan granted or not is a highly significant variable in saving. The co-efficient is 1.679 and hence we can interpret that if loan is granted the probability of saving increases by 1.679 times as compared to the case loan not granted

Distance of Bank: - In the above table we can see that the significance level of distance of bank in the above model is .002 and hence we can say that distance of bank is a highly significant variable in saving. And the coefficient of saving is -1.495 i.e. for each unit of increase in distance of bank the chances of saving decreases by 1.495 times.
Meeting interval: - In the above table we can see that the significance level of meeting interval in the above model is .007 and hence we can say that meeting interval is a less significant variable in saving. And the coefficient of saving is 0.566 i.e. for each unit of increase in meeting interval the chances of saving increases by 0.566 times.

SAVING PRODUCTS AVAILABLE WITH THE SHG IN STUDY

AREA:

\begin{tabular}{|l|l|l|}
\hline Name of deposit scheme & No. of SHG members opting for it & Percentage of SHG members \\
\hline L.I.C. & 70 & $21.90 \%$ \\
\hline G.T.F.S. & 40 & $12.50 \%$ \\
\hline Sahara India & 52 & $16.30 \%$ \\
\hline Prayaag India & 40 & $12.50 \%$ \\
\hline Peerless & 10 & $3.10 \%$ \\
\hline RRB & 167 & $55.67 \%$ \\
\hline Co-operatives & 36 & $12 \%$ \\
\hline BANKS & 300 & $100 \%$ \\
\hline POST OFFICE & 67 & $22.33 \%$ \\
\hline
\end{tabular}

THE SUITABLE SAVING PRODUCTS FOR THE POOR:

\begin{tabular}{|c|c|c|c|}
\hline 8.1.1. & Demand & 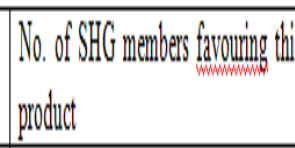 & 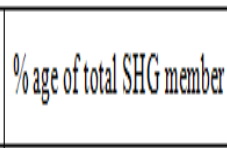 \\
\hline ! & Hones SafeAccount & 50 & $16.6 \% \%$ \\
\hline 2 & Dadyshinghrododut & 62 & $20.6 \%$ \\
\hline 3 & 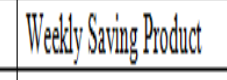 & 68 & $226 \% \%$ \\
\hline 4 & Norady yaling Product & 120 & WNo \\
\hline
\end{tabular}

\section{FINDINGS}

1. It is found that $9.4 \%$ of SHG members do not attend the meeting. More importantly all the defaulters in repayment of loan do not attend meeting regularly.

2. Poor people suffer a lot due to their illiteracy and unawareness. Many a times it was observed that the SHG did not get the loan because they could not pay bribe to officials. Among the 300 members interviewed only $55.3 \%$ of them were granted loan and rest $44.7 \%$ did not get the loan from any bank or any other financial institution.

3. Still the youth are not conscious in these areas towards their personal and social development. As the share of age group 21 to 30 in the sampled villages are only $11.33 \%$.

4. Majority $(74.66 \%)$ of sampled population are illiterate or with no formal education and only $20 \%$ of sampled SHG members are matriculate which again shows that the sampled area (Supaul district) is still lagging in many development issues including human development.

5. $113(37.66 \%)$ out of 300 of respondents complained that they do not get timely payment by the bank. Not only loans but also the money deposited by them is not paid when demanded. 
The bankers usually complain of lack of fund in the branch, and they ask to come after a few days. Some SHG members complained that in this way they lose the wages of that day they could have earned otherwise. And even sacrificing the whole day wage sometimes does not work. In such a situation, it is not feasible for anyone to afford to deposit his/her savings with bank. Poor people prefer to keep money in their houses, rather than depositing with the bank branch.

6. $50(16.66 \%)$ out of 300 depositors accepted that bankers demand bribe for various kinds of work such as sanction of loan, grading opening of savings account with the bank etc. In such situation it is not feasible for anyone to deposit their saving with the bank.

7. $290(96.9 \%)$ out of 300 respondents complained that they were not given information regarding various schemes of bank

8. $64(21.33 \%)$ out of 300 respondents complained that they were not provided with passbook. The bankers usually give excuse that the printer is not working and they have forwarded a complain to their senior authorities, as many as $20(6.66 \%)$ complained that they could not got the account number. These situations compel poor people not to bank upon the bank.

9. As many as $10(3.33 \%)$ out of 300 said that the bankers do close the gate of bank even during banking hours.

10. As many as $83(27.67 \%)$ out of 300 respondents complained about unusual delay in all the work, and the reason being the expectation of bribe for any kind of work.

\section{CONCLUSION}

- Banks should improve their services in the rural area; it is because poor service is one of the factors for low savings potential especially in rural area. Banks should go for specialized SHG branches

- NGOs should be promoted to form and look after the activities and progress of self help groups. It was found that SHGs running under the guidance of Jeevika were doing very well as compared to other SHGs

- Loan should be distributed among self-help groups. It is suggested because those SHGs who had got the Bank loan were involved in some of the activities and had generated the income compared to the SHG members who had not got the loan and as a result were not involved in any income generating activities.

- Employment training should be given to the self-help groups. Employment training will also help in initiation of money generating activities.

- Only one bank had appointed Banking Facilitator. So rest of the banks should also appoint BC/BF. Results show that people will save more if bank employees come to their doorstep.

- A regulatory body should be set up by RBI to sort out the problems of poor people regarding bank branches.
- One working day in a week should be reserved for SHG members.

- Since male members are good at getting the loan sanctioned females are good in terms of attendance in meeting or understanding of responsibility, a group of mix gender would be more effective.

\section{REFERENCES}

1. (2007). A Study on SHG-Bank Linkage and Status of MFI in Bihar. patna: Basics Ltd.

2. Augusto, T. B. (2006). The Basic Analytics of Access to Financial. Mimeo.

3. Bhandari, A. K. (2009). Access to Banking Services and Poverty Reduction: A State-wise Assessment in India. IZA , 3.

4. Bihar govt. website. (n.d.). Retrieved 06 03, 2011, from Bihar govt. website: gov.bih.nic.in

5. bihar online.gov.in. (n.d.). Retrieved 06 02, 2011, from biharonline.gov.in: http://www.biharonline.gov.in

6. Ghate, P. (2010). Microfinance in India: A State of the sector Report,2010. New Delhi: SAGE Publication India Pvt. Ltd

7. Govt. of India (2011), Economic survey 2010-11, New Delhi Ministry of Finance. (2011). Economic survey 2010-11. patna: government of bihar (finance department).

8. K.G.Karmakar. (2009). Microfinance in India. New Delhi: SAGE Publication India Pvt Ltd.

9. Mohan, R. (2006, March). Agricultural Credit in India- Status, Issues and Future Agenda. Economic and Political Weekly, pp. 18-24.

10. Neha. (2011). Scope of BCs in rural areas of Bihar. Lucknow: BIRD. 